\title{
Implementation Of Contextual Teaching and Learning (CTL) to Improve The Geography Learning Outcomes
}

\author{
Deasy Arisanty, Nevy Farista Aristin, M. Nasrullah \\ Department of Geography Education, Faculty of Teacher Training and Education \\ Universitas Lambung Mangkurat \\ Banjarmasin, Indonesia \\ deasyarisanty@unlam.ac.id
}

\begin{abstract}
The students in class X of SMAN 10 Banjarmasin has the low of learning outcome for geography study due to the low motivation of students. CTL approach uses to increase the motivation and to increase the learning outcomes of students. The objective of study is to improve the students learning outcomes of geography using the Contextual Teaching and Learning (CTL). This study uses a quasi-experimental using both pretest and posttest control group design. The population in this study is a class $X$ at SMAN 10 in Banjarmasin. Sampling technique is cluster sampling technique. Samples of research is class $X-3$ as the experimental class with the number of respondent is 34 students and class $X-2$ as the control class with the number of respondent is 36 students. Primary data collection technique use observation and test methods. Data is analyzed using the percentage of enforceability, the calculation of the gain, and the t-test. The results of research shows that the percentage of CTL implementation is $83 \%$ or the excellent category. The result of the gain calculation shows that there is a very significant in the experimental class, $t_{\text {count }}=23.326$. Gain calculation of control class is $\mathbf{1 0 . 7 2 1}$. The result of experimental class is greater than the control class. The result of the calculation of the t-test is $t_{\text {count }}=6.246$, degree of freedom $(d f)=68, t_{\text {table }}$ at $1 \%$ significance level $=2.39$, and $t_{\text {table }}$ at the $5 \%$ significance level $=1.67$. $t_{\text {count }}$ is greater than $t_{\text {table }}$ at significant level of $1 \%$ and $5 \%(6.246>2.39>$ 1.67). The result of calculation shows that there is a difference of geography learning outcomes both experiment class and control class. Geography learning outcome using CTL is better than a conventional method.
\end{abstract}

Keywords-CTL, Learning Outcomes, Geography

\section{INTRODUCTION}

Education refers all efforts planned to realize the human as an individual to develop his or her potential to be strong in personalities, religious, uphold, life prosperous, noble, and necessary skills [1][2]. The educational goals can be successful if the learning process is going well.

The learning process has the components to achieve the goal. Reference [3] states that the component is part of a system that has a role in the overall course of a process to achieve system goals. The components of learning include educational objectives, learners, educators, substance or subject matter, approaches, strategies and methods, media or tools, learning resources and evaluation. One important component is the learning model. Learning model is a conceptual framework and a systematic procedure used as a guide both in the classroom learning and classroom tutorial presented by teachers. Learning model will be able to organize a learning experience to achieve the learning objectives [4][5][6].

Learning is a process characterized by a change of knowledge, understanding, attitudes and behavior as a result of their experience with the environment [3][7], and [8]. The success or failure of education goals relies on the learning process experienced of students both in school and in home environment or family members [9].

Selection of learning models should also notice the depth of material and suitability of material being taught, students' characteristics, the teachers' competence and facilities. Contextual Teaching Learning (CTL) is a learning model that emphasizes the involvement of the students to remember the academic material and to connect material with real life situations and to increase students' motivation [4][10][6][11]. CTL makes students construct the knowledge through the analysis and synthesis processes [11].

CTL have more advantages for students. CTL makes high motivation of students to write, high participation in writing class, determining the topic and main idea of writing, developing their writing, helping to solve the problem, preparing way for students to be involved in a discussion and to interact with their friends, helping students to summarize the learning [12][13].

References [4] and [5] states that the Contextual Teaching Learning (CTL) has seven principles underlying the implementation of the learning process. The seven principles are (1) Constructivism, (2) Inquiry, (3) Question, (4) Community Learning, (5) modeling, (6) Reflection (7) Ratings Real.

Reference [14] explains that the problems in geography learning is too much information to be delivered, but too little time available, so that students are not able to explore information, especially on resources beyond textbooks and teachers. The students feel uninterested, bored, and difficult 
during geography learning. Students only learn a theory without practice; hence students' learning outcomes on geography is very low. Teacher should be able to solve learning problem on geography and to achieve the learning objectives.

CTL makes the lithosphere material fun and interesting. Students interested in the material may increase their learning outcomes. Reference [7] states that the results of learning correlate to the ability of students in receiving learning experience. Obtaining good learning outcomes indicates the good learning process.

CTL can increase students' motivation, and students' learning outcomes in geography lessons [7]. CTL can also improve students' critical thinking skills in geography lessons [15] due to the increasing of students' creativity.

\section{RESEARCH METHODS}

This research used a quasi-experimental research. Quasi experiment is defined as an experiment that has treatment, impact measurement, and experimental units. Variable control is not used fully to control external variables that affect the implementation of the experiment [16]

The research used Nonequivalent Pretest-Posttest Control Group Design. Nonequivalent Pretest-Posttest Control Group Design were two groups of subjects, i.e. one treated and one group as a control group. The population of research is a class $\mathrm{X}$ at SMAN 10 in Banjarmasin. Samples of research are class $\mathrm{X}-3$ as the experimental class with 34 students as the respondents and class X-2 as the control class with 36 students as the respondents.

Pretest and posttest were used to get the learning outcome in the experimental class and control class. The research instrument used in this study was multiple choice questions with 10 points of questions. The research used SPSS 16. Validity and reliability were used for instrumental testing. Validity is presented in equation 1 and reliability is presented in equation 2 [17].

$$
\begin{gathered}
r_{x 1}=\frac{n\left(\sum x Y\right)-\left(\sum x\right)\left(\sum Y\right)}{\sqrt{\left[n \sum X^{2}-\left(\sum x\right)^{2}\right)\left[n \sum Y^{2}-\left(\sum Y\right)^{2}\right)}}(1) \\
K R_{20}=\frac{n}{n-1}\left[\frac{s_{t}^{2}-\sum p q}{s_{t}^{2}}\right] \text { (2) }
\end{gathered}
$$

The research used difficult test and different test. Data analysis was independent sample t-test. Data were analyzed using Gain Score of students learning outcomes derived from the pretest and posttest. The analysis used SPSS 16. Independent t-test is presented in equation 3 [17].

$$
t=\frac{R_{1}-R_{2}}{\sqrt{\frac{s_{1}^{2}}{N_{1}}+\frac{s_{2}^{2}}{N_{2}}}}(3)
$$

\section{RESULTS AND DISCUSSION}

Gain score calculation function is used to determine a significant difference between the values obtained in the students' pretest and posttest. Score Gain calculation results are presented in Table I below.
TABLE I. DIFFERENCES BETWEEN PRETEST AND POSTTEST

\begin{tabular}{|c|c|c|c|c|}
\hline No & Class & The number & \multicolumn{2}{|c|}{ Difference (Gain) } \\
\cline { 4 - 5 } & & 36 & $\mathbf{t}_{\text {count }}$ & $\mathbf{t}_{\text {table }}$ \\
\hline 1 & $\begin{array}{c}\text { X-2 } \\
\text { (control class) }\end{array}$ & & 10.721 & 2.04 \\
\hline 2 & $\begin{array}{c}\text { X-3 } \\
\text { (experimental class) }\end{array}$ & 34 & 23.326 & 2.04 \\
\hline
\end{tabular}

The significant value is difference between pretest and posttest values, both in control group class and experimental group class. This can be seen in both classes that t-count are greater than $t$-tabel. The control group got the $t_{\text {count }}(10.721)>t$ table $(2.04)$ and the experimental class got the $t_{\text {count }}(23.326)>t$ table (2.04).

Based on the results it can be concluded that the provision of pretest and posttest is important in learning activities due to the holding of pretest, in which a teacher can know the basic capabilities of students. Posttest is used as an evaluating instrument for the students' understanding on the learning material delivered by the teacher. The increasing of pretest to posttest value explains that the students understand about learning material delivered by the teacher. The data of students' learning outcomes between the pretest and posttest for the experiment class is higher than that of the control class. The research result explains that the CTL increases the

\begin{tabular}{|c|c|c|c|c|}
\hline \multirow[t]{2}{*}{ No } & \multirow[t]{2}{*}{ Class } & \multirow{2}{*}{$\begin{array}{l}\text { The Number } \\
\text { Of Students }\end{array}$} & \multicolumn{2}{|c|}{ Average Score } \\
\hline & & & Pretest & Posttest \\
\hline 1 & $\begin{array}{c}\text { X-2 (Control } \\
\text { Class) }\end{array}$ & 36 & 56,94 & 68,61 \\
\hline 2 & $\begin{array}{c}\mathrm{X}-3 \\
\text { (Experimental } \\
\text { Class) }\end{array}$ & 34 & 60,29 & 87,94 \\
\hline
\end{tabular}
learning outcomes when compared with the conventional one.

TABLE II. AVERAGE VALUE OF PRETEST AND POSTTEST

Based on Table 2 that the pretest value is almost the same between control class and experimental class. Score in posttest between control class and experimental class are different. Posttest score in the experimental class is higher than that of control class due to the CTL is more effective for geography learning when compared with the conventional method.

Prerequisite test uses the normality test and homogeneity test. Normality test uses the Kolmogorov-Smirov's formula. Normality test value of experiment class is 0.058 , while that of the control class is 0.110 . Both values are greater than 0.05, hence the data are in the normal distribution. Homogeneity test uses the $\mathrm{F}$ test, that experimental class and control class show 0.174. This value is more than 0.05 , meaning that Geography learning students have a homogeneous variant.

Hypothesis testing is done by using the Independent Sample t-Test in SPSS 16.0 for Windows. The test result is Sig (2-tailed) $\leqslant 0.05 \quad(0,000 \leqslant a \quad 0.05)$. The result of research is that $\mathrm{HO}$ is rejected and $\mathrm{Ha}$ is accepted, meaning that there is a significant difference of learning outcome between CTL and conventional learning. The result of the calculation of the t-test shows $\mathrm{t}_{\text {-count }}=6.246$, degree of freedom $(\mathrm{df})=68, \mathrm{t}_{\text {table }}$ at $1 \%$ significance level $=2.39$, and $\mathrm{t}-$ table at the $5 \%$ significance level $=1.67 . \mathrm{t}_{-}{ }_{\text {count }}$ is greater than $\mathrm{t}$ table at significant level of $1 \%$ and $5 \%(6.246>2.39>1.67)$. 
The results of this research indicates that CTL can improve students' learning outcomes on geography in class $\mathrm{X}$ at SMAN 10 Banjarmasin. These results indicate that CTL is more effective than that of conventional learning.

CTL is a learning model that emphasizes the process of students' involvement to determine the learning material related to real life situations, then apply it in their lives [4]. CTL forms a system for students to see meaning and remember the academic material [10].

CTL makes students feel pleased during learning process in the classroom. Students are also more active and creative related to the real life. Students are more active in expressing ideas and thoughts either independently or in groups. CTL makes students understand more about material of learning. Students are easier to answer the questions.

The results of this research can be concluded that the students of experimental class using CTL are more active and creative for expressing ideas than than those of the control class. Students become active using CTL, hence students can understand better not only to ask independently, but also in groups. The results are supported by [14], that there is significant influence of application of CTL for geography learning outcomes when compared with the conventional methods..

Excess of CTL is more meaningful and real, due to the students are guided to find the concept through discussion groups. Students have linking skills, thinking abilities, and social skills. Students can develop an the depth idea. Students can do tasks related to their interest. Subject matter of the soil is more effective using CTL. Soil is the object of study related to real life; hence students easily associate with the concepts of soil.

Results of research shows that there are six key differences between using CTL and conventional methods, i.e.:

a. CTL makes students more active and creative when compared with the conventional method

b. CTL makes students reconstruct the subject matter through group work and assignment, while the conventional method makes students memorize the subject matter

c. CTL uses environment as a learning resource, while the conventional method uses the information of teachers and textbooks as a learning resource.

d. CTL is centered on the students, while the conventional method is a teacher-centered learning

e. CTL process of learning is independently conducted by each student or in groups, while the conventional method of learning occurs between teachers and students

f. CTL is supported by instructional media as the modeling material, whereas conventional methods refer to the drawings in book.

\section{CONCLUSION}

CTL is more effective for improving of students learning outcomes in soil matters. CTL is easy to implement due to it related to the real life, so that students easily associate with the concepts of soils. In addition, CTL makes students develop deep idea. CTL makes students more active when compared with the conventional methods.

\section{REFERENCES}

[1] S. Notoatmodjo, Pendidikan dan Perilaku Kesehatan. Jakarta: PT Rineka Cipta, 2003.

[2] Nurwani, Eli, Aunurahman dan Andy Usman, 2014. Implementasi strategi pembelajaran kontekstual pada pelajaran IPS terpadu untuk perolehan belajar siswa. Jurnal Pendidikan dan Pembelajaran. p.1-12. (http://jurnal.untan.ac.id/index.php/ipdpb/article/download/6998/7958, accessed 30 Maret 2015)

[3] Slameto, Belajar dan Faktor-Faktor yang mempengaruhinya. Jakarta:Rineka Cipta, 2010

[4] W. Sanjaya, Strategi Pembelajaran Berorientasi Standar Proses Pendidikan. Jakarta: Prenada Media Group, 2007

[5] A.Suprijono, Cooperative Learning: Teori dan Aplikasi PAIKEM. Yogyakarta: Pustaka Belajar, 2009.

[6] A. Majid, Strategi Pembelajaran. Bandung: PT Remaja Rosdakarya, 2014

[7] W. Kristanti, Pengaruh Metode Pembelajaran Kontekstual Terhadap hasil Belajar IPS Geografi Kelas VII SMPN 18 Balikpapan Ditinjau dari Motivasi Belajar Siswa Tahun Pelajaran 2009/2010. Surakarta: Universitas Sebelas Maret, Tesis, 2010. (http://eprints.uns.ac.id/6159/1/171461412201008581.pdf, accessed 30 Maret 2015)

[8] Fikriaryar, Penerapan Metode KOGA (Kontekstual dan Gambar) untuk Meningkatkan Prestasi Belajar Siswa pada Mata Pelajaran IPS Terpadu Kelas VIIG SMP Negeri 8 Purwokerto, Skripsi, 2012

[9] A.A. Nata, Cara Belajar Siswa Kelas VII SMP Negeri 33 Banjarmasin Tahun Ajaran 2013/2014 dalam Menghadapi Ulangan Akhir Semester Ganjil. Banjarmasin: FKIP UNLAM, skripsi, 2014.

[10] E.B. Johnson, Contextual Teaching and Learning: Menjadikan Kegiatan Belajar-Mengajar Mengasyikkan dan Bermakna. Bandung: Mizan Learning Center, 2009.

[11] C.C. Hudson, and V.R. Whisler,"Contextual teaching and learning for practitioner". Systematics, Cybernetics and Informatics journal, Vol. 6, No 4, 2008 .

[12] I. Satriani, E. Emilia, and M.H., Gunawan, "Contextual teaching and learning approach to teaching writing", Indonesian Journal of Applied Linguistics, Vol. 2 No. 1, pp. 10-22, 2012

[13] S. Tiningsih, Yuniarsa, S. Octa, "Writing skills enhancement using the Contextual Teaching and Learning (CTL) approach in Jayapura", International Journal of Business, Economics and Law, Vol. 5, Issue 2, 2014.

[14] I.K., Arta, Pengaruh penerapan model CTL (Contextual Teaching and Learning) berbantuan media pembelajaran terhadap hasil belajar Geografi siswa kelas X di SMA Negeri Nusa Penida tapel 2012/2013. Jurnal Jurusan Pendidikan Geografi. p. 1-11, 2013 (http://ejournal.undiksha.ac.id/index.php/JJPG/article/viewFile/1107/97 0, diakses 30 Maret 2015)

[15] T.I., Kurniasih, Pengembangan Model Pembelajaran Contextual Teaching and Learning (CTL) Menggunakan Media Pembelajaran Movie Maker untuk Meningkatkan Berfikir Kritis Geografi Siswa Kelas XI SMA Negeri 10 Bandar Lampung Tahun pelajaran 2015/2016. Lampung, Universitas Lampung, Tesis, 2016.

[16] Cook and Campbell, Quasi and Experimentation: Design and Analyze Issues for Field Setting. Houghton Mifflin Co, 1979

[17] E. Riadi, Statistika Penelitian (Analisis Manual dan IBM SPSS). Andi Offset. Yogyakarta, 2016. 